\title{
Review of Literature on Finance-Growth Nexus
}

\author{
Najia Saqib ${ }^{1}$
}

\begin{abstract}
This study discusses the current state of knowledge on the financial development and economic growth by reviewing the most decisive theoretical and empirical contributions. It is obvious that financial development is at least correlated with economic development and that a sound and refined financial system encourages the efficiency of investment and economic growth in a market economy. It is also observable that an inadequately functioning financial system can obstruct economic growth and development. The review highlights that most empirical studies focus on either testing the role of financial development in motivating economic growth or tentative direction of causality between these two variables. We review the cross-country and time series empirical literature in this study. It is evident that searching the relationship between financial development and economic growth is inconclusive across countries, regions, and methodologies employed.
\end{abstract}

JEL classification numbers: E44; G21; O16.

Keywords: Financial Sector; Financial Institutions; Economic Development.

\section{Introduction}

The origin of the financial development concept goes back to the early work of Gurley and Shaw (1967). They investigate the evolution of the financial structure during economic growth, and argue that financial development is a positive function of real wealth. As countries grow in terms of income and wealth, their financial structures tend to become more sophisticated in terms of institutions and financial assets available. During economic development, as their incomes per capita increases, countries usually experience more rapid growth in financial assets than in national wealth or national product. Financial growth in excess of real growth is apparently a common phenomenon

\footnotetext{
${ }^{1}$ Assistant Professor of Economics, Business Administration Department, Prince Sultan University, Riyadh-Kingdom of Saudi Arabia.
}

Article Info: Received: January 20, 2015. Revised : March 2, 2015.

Published online : July 1, 2015 
around the world over time. For any one country as its income per capita increases, financial assets rise relative to national real wealth. ${ }^{2}$

The role of financial development in economic growth has been examined both theoretically and empirically in the recent literature. However, this debate is not new in the development economics literature and can be traced back to Schumpeter's (1912) Theory of Economic Development. Since then this issue had been extensively studied by Goldsmith (1969), McKinnon (1973) and Shaw (1973) and others, who produced considerable evidence that financial development correlates with economic growth. They consider that all forms of public control on the financial market achieved by quantitative instruments (directed credits for selected strategic sectors, high reserve ratios) or price instruments (interest rate ceiling) generate a financial repression situation characterized by negative real interest rates, low levels of savings, investments and therefore, growth. Consequently, they have underscored the need for financial liberalization, the elimination of all forms of public intervention and freeing the real interest rate. However, their work through insightful, lacked analytical foundation. The recent revival of interest in the link between financial development and growth stems mainly from the insights and techniques of endogenous growth models. Since economic growth may come from the growth in the factors of production or increases in the efficiency with which those factors are used. Financial development basically affects economic growth by increasing the saving rate, thereby raising the level of investment. Furthermore, by efficiently allocating the available resources, it increases the productivity of investment. ${ }^{3}$

\section{Theoretical Literature}

The aim of this section is to outline the main theoretical approaches' modeling the linkages between financial development and economic performance, together with a methodological description of the empirical analyses erected upon such a theory. Financial development facilitates economic growth through five channels as presented by Levine (2004). These five channels are:

(i) Producing information and capital allocation,

(ii) Monitoring firms and exerting corporate governance,

(iii) Improving risk management,

(iv) Polling savings and

(v) Facilitating the exchange of goods and services.

Each of these functions can also manipulate the financial savings, investment decisions and economic growth ${ }^{4}$.

One of the important functions of the financial system is to assist capital flows from savers to the highest return investment (Levine, 2006). Financial intermediaries and companies have a close relationship, further reducing the cost of obtaining information. Imperfect information may, in turn, ease external financing problems and a better allocation of resources. Financial markets and institutions promote improvements in the

\footnotetext{
${ }^{2}$ Gurley and Shaw (1967:257-258)

${ }^{3}$ See, Pagano (1993) and Levine (1997) for a comprehensive survey of the literature.

${ }^{4}$ See Levine (2004:5)
} 
control of the company and a rapid accumulation of capital and promote economic growth through better allocation of capital. An additional function of financial institutions is to reduce the cost of acquiring information and monitoring of investment projects.

Diamond (1984) develops the model of financial development based on reducing the cost of monitoring information, which is useful for solving the problems on incentives between borrowers and lenders ${ }^{5}$. It provides incentives for the characterization of the cost of delegated supervision of financial intermediaries. Diversification reduces the costs even in risk neutral economy. The model presents a general analysis of the diversification effect on solving problems and assumed debt contracts in costly bankruptcy are shown to be optimal. Financial development allows better contracts to be used and allow Pareto superior allocation.

Boyd and Prescott (1986) analyze that financial intermediaries can reduce the costs of acquiring and processing information, and then improve the allocation of resources. Without intermediaries, each investor would face the high fixed costs associated with businesses to assess managers and economic conditions. Accordingly, groups of individuals may form financial intermediaries that perform the expensive process of seeking investment opportunities for others.

Greenwood and Jovanovic (1990) analyze that financial intermediation and economic growth are determined endogenously. Financial intermediation promotes economic growth because it provides a higher rate of return on equity, and in turn it allocates resources. Their model investigated that the capital may be invested for getting a lowyield technology or high-yield technology. Low yield technology is safe and get low rate of return, but the high-yield technology is risky and investors get the high rate of return. There are two terms for the high rate of return on risky technology such as cumulative shock and particular project shock. Unlike their large portfolios of individual investors by financial intermediaries can perfectly decode the aggregate productivity shock and therefore, to choose the best technology for the current perception of the shock. Therefore, financial intermediaries, savings and productivity through more efficient allocation of capital lead to greater economic growth.

Holmstrom and Tirole (1993) argue that stock markets can increase incentives for investors to get information about firms and improve corporate governance. Companies would issue shares in capital markets because their shares are publicly traded, speculators will collect information on company's performance, so the complete information gathers at the least price. The company will be able to compensate for the manager on the stock prices, thus efficient incentives make efforts and improve business performance, and then it is easier to profit from this information by trading in large and liquid markets. Existing theories have not yet put together a chain of a link between the stock market liquidity creates information acquisition, and then it stimulates the higher economic growth.

King and Levine (1993b) construct an endogenous growth model for financial development and long-run economic growth. Modernize financial system initiates technology and thereby increasing the economic growth. Similarly inefficient financial system reduces the rate of economic growth by reducing the technology. Financial systems assess the potential investors, mobilize savings to invest in productive activities, diversification of the risk which is associated with productive activities and then enhance the high rate of return. In these ways, modernized financial systems encourage economic growth rate by increasing the productivity enhancement.

${ }^{5}$ See detail review Diamond (1984:1) 
Galetovic (1996) analyzes that in market economies financial intermediaries develop during the early stages of industrialization. The author argues that it occurs because the number of transactions involving credit increases due to the firm's specialization. The author concludes that sustained growth may not start before financial intermediaries do not emerge. In this sense, financial development is a necessary condition for growth to start and persist and when firms specialize in intermediaries endogenously emerge, because they prevent the repetition of monitoring effort.

DeGregorio (1996), in fact, suggests that the relationship between borrowing constraints and growth will ultimately depend on the importance of the effect of borrowing constraints on the marginal productivity of capital relative to their effect on the volume of savings. In particular, the study shows that a relaxation of borrowing constraints increases the incentives for human capital accumulation. This effect is likely to increase the marginal product of capital and, hence, may lead to higher growth despite the reduction in savings.

Blackburn and Hung (1998) analyze that savings are not fully allocated to investment because some of them are consumed in transaction costs. Authors found the positive relationship between financial development and economic growth. If there are no intermediaries in the economy means every investor needs to monitor a project, and the monitoring cost would be doubled. However, if the financial sector is going to be more efficient than the monitoring tasks can be given to intermediaries. Due to this, transition costs are reduced and more saving attributable to investment in order to produce innovations and accelerate economic growth can be achieved. Authors have also explained that how an economy can be entrapped in a circle of low financial development and economic growth. They conclude that monitoring cost will be too high for financial intermediation, and the economic growth stays very low if the monitoring cost remains too high and results in low financial development in an economy.

Corporate governance is the central concept of economic growth and financial development. The investors of capital to a company monitor and manipulate the usage of capital effectively because capital effects on saving as well as allocation decisions. Investors effectively monitor companies and persuade managers to take full benefit of company's assessment; this will improve resource allocation and make savers more willing to invest for production and innovation.

Shleifer and Vishny (1996) confirmed that financial intermediaries that function efficiently improve the monitoring of investment activities and enhance corporate governance. Owing to the existence of market frictions such as high transaction costs and information asymmetries, diffused shareholders may be prevented from exercising adequate control over the managers of the firms. The problem of corporate governance can be ameliorated by smooth functioning of financial arrangements.

Bencivenga and Smith (1993) develop an endogenous growth model which shows that financial intermediaries improve corporate governance by cutting back the monitoring costs that will result from credit rationing and thus improvements in technology for increasing productivity, capital accumulation, and economic growth.

Sussman (1993) and Harrison, Susman and Zaira (1999) develop models where the financial structure facilitates the resources flow from savers to investors in the presence of complete information, and that's leading to higher economic growth.

De la Fuente and Marin (1996) develop a model in which they analyze the relationship between capital accumulation, technological innovation and financial development. These variables have improved the allocation of credit among competing technology producers 
and encouraged the economic growth. The financial intermediaries must prevent overlapping of monitoring activities and incentive to negotiate contracts with innovators. Further, they conclude that higher the innovative activity faster the economic growth, thus lowering the monitoring cost that leads to increase in the efficiency of the financial sector. Laeven and Levine (2008) conduct the assessment of the theories concerning taking a risk by banks, ownership structure and public sector bank regulation. They emphasize frictions between managers and owners over risk and conclude that risk taking by a bank have a positive impact on corporate governance structure of each bank through the power of shareholders. Further, they show that the regulation has different effects on risk taking by banks depending on the corporate governance structure of the bank.

The financial systems mitigate the risks associated with individual projects, companies, industries and countries. Risk diversification has increased the saving rate and allocate resources efficiently that leads to higher economic growth. The high return rate project is riskier than the lowest return rate projects, but in high return projects investors get a high profit. The financial systems facilitate the diversification of the risk, causing a shift to a higher-yielding portfolio in projects.

Patrick (1966) hypothesized a bi-directional association between financial development and economic growth. Two trends in the literature can be identified. The first, testing the association between economic growth and financial development, habitually assumes a single measure of financial development and analyses the hypothesis on several countries by either cross section or panel data techniques.

Hicks (1969) argued that the industrial revolution was not the immediate consequence of a set of new technological innovations, rather the consequence of financial innovations, which allowed the implementation of this technological innovation on a large scale through large investments. Many products and technologies have been already available decades earlier than the start off of the industrial revolution. Capital liquidity allowed these technologies to be extensively applied. ${ }^{6}$

Greenwood and Jovanovic (1990) developed a model in which both financial development and growth are endogenously determined. With respect to the growth effects of financial development, they demonstrated that by pooling idiosyncratic investment risks and eliminating ex-ante uncertainty about rates of returns, financial development can lead to faster growth.

Bencivenga and Smith (1991) emphasize that the primary function of the financial system is to facilitate the allocation of the resources and more specifically, financial system facilitates the risk management. At the same time, diversification makes possible the financing of riskier but more productive investments and innovations.

Bencivenga, Smith and Starr (1995) extend the theory and propose the model; it was shown that the development of banks increases economic growth by channeling savings to the activity with higher productivity.

Jacoby (1994) found that lack of access to credit perpetuates poverty because poor households reduce their kids' education. In particular, financial arrangements may facilitate borrowing for the accumulation of skills. If human capital accumulation is not subject to diminishing returns on a social level, financial arrangements that ease human capital creation help accelerate economic growth.

Mobilization saving is another important channel of financial development, which facilitates the economic growth. The mobilization is the costly process of agglomerate

${ }^{6}$ Hicks (1969:143-145) 
capital from disparate savers to investors. It involves overcoming the transaction costs of collected savings from innumerable individuals, and the information asymmetries associated with making savers feel comfortable in relinquishing control of their savings. Saving mobilization become possible through financial market and financial intermediaries. Mobilization of savings through financial markets has several bilateral agreements between production units raising capital and agents with surplus resources like the joint-stock company have many individuals invest in one entity. Mobilizations of savings through intermediaries have several investors who entrust their wealth to banks that invest in numerous firms. Encouraging saving mobilization enhance capital accumulation that leads to the improvement of resource allocation and increases technological innovation and economic growth.

Acemoglu and Zilibotti, (1997) concluded that financial intermediation mobilizes and pools savings. It thereby not only fosters capital accumulation in the economy but also contributes to a better resource allocation as it allows exploiting economies of scale and overcoming investment indivisibility.

Sirri and Tufano (1995) propose that households would be obliged to purchase and sell whole firms exclusive of pooling savings. Therefore, through the mobilization of financial capital, households are able to improve their liquidity and risk diversification, and encourage the productive sector of the country by the appropriate allocation of resources. To economize on the costs associated with multiple bilateral contracts, pooling may also occur through intermediaries, where thousands of investors entrust their wealth to intermediaries that invest in hundreds of firms. ${ }^{7}$

Roubini and Sala-i-Martin (1992) analyzes the relationship between the degree of financial development and the growth performance of large cross-section of countries at the theoretical and empirical levels. They presented a theoretical model of financial development, inflationary finance and endogenous growth. ${ }^{8}$ They showed that financial repression reduces productivity of capital, lowers savings, and reduces the growth rate of the economy.

Bagehot (1873) argued that a major difference between England and poorer countries was that in England, the financial system could mobilize resources for "immense works." Thus, good projects would not fail for lack of capital ${ }^{9}$. Bagehot was very explicit in noting that it was not the national savings rate per se, it was the ability to pool society's resources and allocate those savings toward the most productive ends.

Adam Smith's (1776) Wealth of Nations analyzed the relationship between easing exchanges, specialization, innovation, and economic growth. He argued that the division of labor (specialization) is the principal factor underlying productivity improvements. With greater specialization, workers are more likely to invent better machines or production processes. ${ }^{10}$ I shall only observe. Therefore, that the invention of all those machines by which labor is so much facilitated and abridged, seems to have been originally owing to the division of labor. Men are much more likely to discover easier and readier methods of attaining any object, when the whole attention of their minds is

\footnotetext{
${ }^{7}$ See Sirri and Tufano (1995:83)

${ }^{8}$ They argued that one of the reasons why some governments may choose to repress the financial sector is that it delivers easy inflationary revenue since financial repression induces private sector to carry a larger stock of nominal money, the base for the inflation tax.

${ }^{9}$ Bagehot (1873:3-4)

${ }^{10}$ Adam Smith (1776:7)
} 
directed towards that single object, then when it is dissipated among a great variety of things. ${ }^{11}$ Author phrased his argument about the lowering of transaction costs and technological innovation in terms of the advantages of money over barter. ${ }^{12}$

Greenwood and Smith (1997) develop a model wherein financial markets promote specialization and reduce transaction costs, which lead to productivity gains that translate into higher growth. Financial institutions also reduce liquidity risk as they allow the transformation of liquid financial assets (that are desirable by the savers) into long-term capital investments. Furthermore financial markets modernize information costs on investment opportunities and thus improve the allocation of capital.

\section{Empirical Literature}

Although literature replicates the close association linking of financial development and economic growth, it is probable to come across particularly empirical researches providing evidence to all potential as positive, negative, no connection or insignificant relationships. Empirical studies have attempted to assess the qualitative and quantitative impact of financial development on economic growth through the use of different types of econometric methods and a variety of indicators to measure financial development. The result of most of the studies suggests that financial development has a positive impact on economic growth.

\section{Cross Country Studies}

First to examine the relationship between finance and growth is conducted by Raymond Goldsmith (1969). Goldsmith uses the value of financial intermediary in relation to GDP as a measure of financial development. By examining the data of 35 countries over 103 years $(1860$ - 1963), he finds that financial development and economic growth generally occur simultaneously. Greater complexity of the investigation of Goldsmith's study because he has not used several other factors, which are needed for the determination of causal relationship between financial development and economic growth.

Roubini and Sala-i-Martin (1992) use a Barro-type growth regression model and analyze the relationship between the financial development and economic growth of having crosscountry data for 53 countries over the period 1961-1980. They performed their study theoretically as well as empirically and conclude that the financial repression reduces the productivity of capital and lowers savings, thus hampering growth. The upshot of these theoretical studies is that financial development leads to stronger economic growth.

Atje and Jovanovic (1993) extend the empirical analyses to 94 countries over the period $1980-88$ by using Ordinary Least Square (OLS) method. They considered the credit expansion by private and public banks to GDP, stock market trade to GDP and value of stocks outstanding to GDP as indices. They get considerable relationship between the stock market capitalization and economic growth for forty countries. They conclude that the growth of the stock market has a positive impact on economic growth while bank lending does not have the same effect.

\footnotetext{
${ }^{11}$ Adam Smith (1776:3)

${ }^{12}$ Adam Smith (1776: 26-27)
} 
King and Levine (1993b) analyze cross-country data for 80 countries over the period 1960-1989. They use three growth indicators ${ }^{13}$ and four different indicators of financial development ${ }^{14}$ to determine the relationship between financial development and economic growth. Controlling for other variables that affect long-run growth, they found that different financial indicators were strongly and robustly correlated with economic growth. They also showed that the initial level of financial depth was a good predictor of subsequent rates of economic growth even after controlling for other growth-enhancing factors.

Harris (1997) analyzes data of 49 countries over the period 1980-1991 by using TwoStage Least Square (2SLS) method. They used four different indicators ${ }^{15}$ to determine the correlation between financial development and economic growth. Unlike the results reported by Atje and Jovanovic (1993), this study also finds a little support for the development of the stock market leading to the higher growth per capita of output for low-income countries. However, stock market development has a positive impact on economic growth for developed countries.

Demirguc-Kunt and Maksimovic (1998) analyze cross-country data for 30 countries $^{16}$ over the period 1980-1991 by using Ordinary Least Square (OLS) methodology. They use different variables ${ }^{17}$ to determine the relationship between financial development and economic growth. They conclude that the efficient financial system encourages most of the companies to use at the lower end of external financing. Efficient financial sector allows a more active and well developed legal system and makes easier to get foreign investment, which in turn facilitates the progress of the company's growth. Further, they argue that the government subsidies do not seem to play an important role in these economies.

Levine and Zervos (1998) extend the empirical analyses by studying the empirical relationship between several measures of stock market development, banking development and long run economic growth. They analyze cross-country data for 42 countries over the period 1976-1993 by using Ordinary Least Square (OLS) methodology. They find that both the initial level of stock market liquidity (measured by the turnover ratio $^{18}$ ) and the initial level of banking development (measured by bank credit to the private sector as a ratio of GDP) were robustly correlated with future economic growth.

\footnotetext{
${ }^{13}$ These indicators were (i) long-run per capita growth rates, (ii) capital accumulation and (iii) productivity growth.

${ }^{14}$ These indicators were (i) the ratio of liquid liabilities to GDP; (ii) ratio of deposit money bank assets to total assets; (iii) the ratio of non financial private sector credit to total credit; and (iv) ratio of claims on the non financial private sector to GDP.

${ }^{15}$ These indicators were (i) growth in GDP per unit of effective labor (ii) investment as a percent of GDP (iii) the growth of total employed labor and (iv) the total value of shares traded on the stock market as a percent of GDP

${ }^{16}$ These countries were Brazil, India, Jordan, Korea, Malaysia, Mexico, Pakistan, South Africa, Thailand, Turkey, and Zimbabwe, Australia, Austria, Belgium, Canada, Finland, France, Germany, Hong Kong, Italy, Japan, Netherlands, New Zealand, Norway, Singapore, Spain, Sweden, Switzerland, United Kingdom, and the United States

${ }^{17}$ These variables are real GDP per capital, law and order indicator, common law dummy, creditor rights index, shareholder rights index and turnover ratio

${ }^{18}$ Turnover ratio was measured as value of the trades of domestic shares on domestic exchange divided by the value of listed domestic share.
} 
They concluded that financial development and economic growth have a strong positive link and that financial factors are an integral part of the growth process.

Levine (1999) analyzes cross-country data for 77 countries over the period 1960-1989 by using Generalized Method of Moments (GMM) methodology. The study finds out that increase in financial deepening ${ }^{19}$ is likely to increase total factor productivity. The key findings show a positive relationship between financial development and economic growth, and well legal and regulatory system develops the financial intermediary development, and then it leads to higher economic growth.

Levine, Loayza, and Beck (2000) analyze cross-country panel data set of 74 countries over the period 1960-1995 by using Generalized Method of Moments (GMM) equation. Concerning the measurement of financial development, they introduced the new indicator "private credit," which is defined as the value of credits by financial intermediaries to the private sector divided by GDP. Financial intermediaries comprise both deposit money banks and other financial institutions. Their study finds evidence of a strong link between financial development and economic growth. Their results indicated that the evolution of private credit had a particularly large impact on the growth performance in their sample.

$\mathrm{Xu}$ (2000) uses a multivariate vector autoregressive approach to examine the effects of permanent financial development on domestic investment and output in 41 countries between 1960 and 1993 by using the VAR approach. The results showed that financial development is important to GDP growth and that domestic investment is an important channel through which financial development affects economic growth. Furthermore, many countries could turn the short-term negative effects to long-term positive effects, and all these results were robust.

Demirguc-Kunt and Maksimovic (2002) investigate data on firm-level of 40 developed and developing countries' largest publicly traded manufacturing firms enclose 45598 annual observations over the period 1989-1996. They used different indicators ${ }^{20}$ to analyze how a country's legal and financial systems affect companies' access to external financing to influence the development fund by using Two-Stage Least Squares (2SLS) method. The result of their study is that the impact of the development of the stock market and banking sector on growth of the firms is closely related to the level of development of the legal framework for the relevant country. There is no evidence that the development of a bank-based system or financial market affects access to financing.

Rioja and Valev (2004) investigate the channels through which financial development influences economic growth in a panel of 74 countries during 1961-1995 by using Generalized Method of Moments (GMM) techniques. They used three variables of financial development measures ${ }^{21}$ and three dependent variables ${ }^{22}$ in their study. They found that finance has a strong positive influence on productivity growth primarily in more developed countries. In less-developed countries, the effect of finance on output growth occurs primarily through capital accumulation. Therefore, the contribution of well-constructed financial development for growth in productivity is not the case until a

\footnotetext{
${ }^{19}$ Proxied by the credit to the private sector in percent of GDP

${ }^{20}$ These indicators were real GDP per capita, law and order indicator, common law dummy, creditor rights index, shareholder rights index, turnover, deposit money bank to GDP ratio and market-based system and bank-based system.

${ }^{21}$ These were Private Credit, Commercial vs. Central Bank and Liquid Liabilities

${ }^{22}$ These were real per capita GDP, per capita physical capital stock and rate of growth of the "residual"
} 
country reaches a certain income level, roughly in the range which an average income group describes.

Christopoulos and Tsionas (2004) analyze the data from 10 developing countries ${ }^{23}$ over the period 1970-2000 by using unit root test and panel cointegration analysis to estimate the link between financial development and economic growth. They use financial depth ${ }^{24}$, the share of investment ${ }^{25}$ and inflation rate ${ }^{26}$ to determine the relationship between finance and growth. The authors find well-built verification of the strong relationship between financial development and economic growth and that there is no evidence of bidirectional causality. In addition, they developed a unique cointegration between the finance and growth and emphasized on long-term nature of finance and development.

Aghion et al. (2005) analyze the cross-country data of 71 countries over the period 19601995. They used several financial variables ${ }^{27}$ and other policy variable ${ }^{28}$ to examine how financial development affects the composition of investment and the inferences for instability and growth. They conclude that the response based on volatile and exogenous shocks may be the most important transmission channel as the effects of the credit markets deepened. They argue that financial development explains whether there is convergence or not, but it does not exert a direct effect on steady- state growth.

McCaig and Stengos (2005) examine the cross-country data of 71 countries over the period 1960-1995 by using Generalized Method of Moments (GMM) techniques to analyze the relationship between financial development and economic growth, and they also employed Over-Identifying Regressions (OIR) to test the soundness of the instant conditions and evaluate the quality of the tools to avoid the use of fragile instruments. The result of their study shows a strong positive effect of financial development on economic growth when private domestic credit or liquid liabilities is used as the measures of financial development. However, the link becomes considerably weaker when the ratio of commercial bank assets is used as the indicator of financial development.

Apergis et al. (2007) estimate the link between financial development and economic growth for the data of 101 countries over the period 1975-2000 by using a panel data cointegration methodology. They used different variables ${ }^{29}$ and emphasis on supply and demand leading hypothesis. The foremost view of this study is that there is a reciprocal relationship between financial development and economic growth. Another view is that there is no correlation between them. The result of their study concludes that the financial development and economic growth have a strong relationship, and the causality is bidirectional.

Caporale et al. (2009) study the finance-growth relationship in ten new EU members employing data (1994-2007). Using GMM estimates in a dynamic panel and Granger

\footnotetext{
${ }^{23}$ These countries were Colombia, Paraguay, Peru, Mexico, Ecuador, Honduras, Kenya, Thailand, Dominican Republic, and Jamaica

${ }^{24}$ Financial depth is the ratio of total bank deposits liabilities to nominal GDP

${ }^{25}$ the share of investment is the share of gross fixed capital formation to nominal GDP

${ }^{26}$ Inflation rate is measured using the consumer price index

${ }^{27}$ These variables were Private credit, the value of credit extended to the private sector by banks and other financial intermediaries as a share of GDP.

${ }^{28}$ These variables were share of government in GDP, inflation, the black market exchange rate premium and openness to trade

${ }^{29}$ The liquid liabilities of the financial system, school enrollment, gross fixed capital and general government final consumption expenditure and volume of trade
} 
causality tests they conclude that the development of the banking sector causes growth, while the stock market exerts a limited contribution to the real economy. Furthermore, they find that the causality of the finance-growth relationship is unidirectional, and runs from financial development to growth.

Bangake and Eggoh (2011) use a sample of 71 developed and developing countries and provide estimates based on panel Vector Error Correction Model (VECM), distinguishing among low, middle and high income countries. Their results point toward bi-directional causality in the long run across country groups. In the short run, however, the direction of causality goes from growth to finance for the high income countries, while folow and middle income countries they cannot find any evidence of causality.

Table 1 summarizes the cross-country review of empirical literature results.

Table 1: Cross-Country Evidence on Finance and Growth

\begin{tabular}{|c|c|c|c|}
\hline Study & Sample & Method & Key findings \\
\hline $\begin{array}{l}\text { Goldsmith } \\
\text { (1969) }\end{array}$ & $\begin{array}{l}\text { Annual Data of } 35 \\
\text { countries over } 103 \\
\text { years }(1860-1963)\end{array}$ & OLS & Financial and economic development generally occurs simultaneously \\
\hline $\begin{array}{l}\text { Roubini and } \\
\text { Sala-i- } \\
\text { Martin } \\
(1992) \\
\end{array}$ & $\begin{array}{l}\text { Annual Data of } 53 \\
\text { countries over of } \\
(1961-1980)\end{array}$ & $\begin{array}{l}\text { Barro-type } \\
\text { growth } \\
\text { regression } \\
\text { model } \\
\end{array}$ & Financial development leads to stronger economic growth. \\
\hline $\begin{array}{l}\text { Atje and } \\
\text { Jovanovic } \\
(1993)\end{array}$ & $\begin{array}{l}\text { Annual Data of } 94 \\
\text { countries during the } \\
\text { period (1980-1988) }\end{array}$ & OLS & $\begin{array}{l}\text { Growth of the stock market has a positive impact on economic growth while } \\
\text { bank lending does not have the same effect }\end{array}$ \\
\hline $\begin{array}{l}\text { King and } \\
\text { Levine } \\
(1993) \\
\end{array}$ & $\begin{array}{l}\text { Annual Data of } 80 \\
\text { countries over the } \\
\text { period (1960-1989) }\end{array}$ & OLS & $\begin{array}{l}\text { The initial level of financial depth is good predictor of the outcome of economic } \\
\text { growth. }\end{array}$ \\
\hline $\begin{array}{l}\text { Harris } \\
\text { (1997) }\end{array}$ & $\begin{array}{l}\text { Annual Data of } 49 \\
\text { countries over the } \\
\text { period of (1980- } \\
1991)\end{array}$ & 2SLS & The activity of the stock proved to impact on growth in developed countries. \\
\hline $\begin{array}{l}\text { Demirguc - } \\
\text { Kunt } \\
\text { and Maksim } \\
\text { ovic (1998) } \\
\end{array}$ & $\begin{array}{l}\text { Annual Data } \\
\text { for } 30 \text { countries } \\
\text { over the period } \\
(1980-1991)\end{array}$ & OLS & $\begin{array}{l}\text { A larger banking sector, a more effective stock market allows well } \\
\text { developed legal system. }\end{array}$ \\
\hline $\begin{array}{l}\text { Levine and } \\
\text { Zervos } \\
(1998)\end{array}$ & $\begin{array}{l}\text { Annual Data from } \\
42 \\
\text { countries over (197 } \\
6-1993)\end{array}$ & OLS & $\begin{array}{l}\text { Stock Market essentially nationalized gets a better allocation of resources and } \\
\text { high economic growth. }\end{array}$ \\
\hline $\begin{array}{l}\text { Levine } \\
\text { (1999) }\end{array}$ & $\begin{array}{l}\text { Annual Data from } \\
77 \text { countries over } \\
\text { the period (1960- } \\
1989 \text { ) }\end{array}$ & GMM & $\begin{array}{l}\text { Well legal and regulatory system develops the financial intermediary } \\
\text { development and then it leads to higher economic growth. }\end{array}$ \\
\hline $\begin{array}{l}\text { Levine, Loa } \\
\text { yza and Bec } \\
\text { k (2000) }\end{array}$ & $\begin{array}{l}\text { Annual Data from } \\
74 \\
\text { countries over (196 } \\
0-1995) \\
\end{array}$ & GMM & $\begin{array}{l}\text { The evolution of private credit has a particularly large impact on the growth } \\
\text { performance thereby accelerates economic growth. }\end{array}$ \\
\hline $\mathrm{Xu}(\mathbf{2 0 0 0})$ & $\begin{array}{l}\text { Annual Data from } \\
41 \text { countries during } \\
\text { the period ( } 1960 \\
\text { to } 1993 \text { ) }\end{array}$ & VAR & $\begin{array}{l}\text { Domestic investment is an important channel through which financial } \\
\text { development affects economic growth. }\end{array}$ \\
\hline $\begin{array}{l}\text { Demirguc- } \\
\text { Kunt and } \\
\text { Maksimovic } \\
(2002) \\
\end{array}$ & $\begin{array}{l}\text { Annual Data from } \\
40 \text { countries during } \\
\text { the period (1989 to } \\
1996 \text { ) }\end{array}$ & 2SLS & $\begin{array}{l}\text { There is no evidence that the development of a bank-based system or financial } \\
\text { market affects access to financing. }\end{array}$ \\
\hline $\begin{array}{l}\text { Deidda and } \\
\text { Fattouh } \\
(2002) \\
\end{array}$ & $\begin{array}{l}\text { Annual Data of } 119 \\
\text { countries over the } \\
\text { period (1960-1989) }\end{array}$ & OLS & $\begin{array}{l}\text { The higher the financial development, the higher the economic growth. The } \\
\text { results only apply to higher income countries but not for low-income countries. }\end{array}$ \\
\hline $\begin{array}{l}\text { Rioja and } \\
\text { Valev (2003) }\end{array}$ & $\begin{array}{l}\text { Annual Data of } 74 \\
\text { countries over the } \\
\text { period (1961-1995) }\end{array}$ & GMM & $\begin{array}{l}\text { Financial development for growth in productivity is not the case until a country } \\
\text { reaches a certain income level, roughly in the range with an average income } \\
\text { group describes. }\end{array}$ \\
\hline Study & Sample & Method & Key findings \\
\hline $\begin{array}{l}\text { Christopoul } \\
\text { os and }\end{array}$ & $\begin{array}{l}\text { Annual Data from } \\
10 \text { countries over }\end{array}$ & $\begin{array}{l}\text { Unit Root Test } \\
\text { and Panel }\end{array}$ & $\begin{array}{l}\text { They developed a unique cointegration between the finance and growth and } \\
\text { emphasized on long-term nature of finance and development }\end{array}$ \\
\hline
\end{tabular}




\begin{tabular}{|c|c|c|c|}
\hline $\begin{array}{l}\text { Tsionas } \\
(2004)\end{array}$ & $\begin{array}{l}\text { the period (1970- } \\
2000)\end{array}$ & $\begin{array}{c}\text { Cointegration } \\
\text { Analysis }\end{array}$ & \\
\hline $\begin{array}{l}\text { Aghion et } \\
\text { al. (2005) }\end{array}$ & $\begin{array}{l}\text { Annual Data of } \\
71 \text { Countries over } \\
\text { the period (1960- } \\
1995)\end{array}$ & & $\begin{array}{l}\text { Financial development explains whether there is convergence or not but it does } \\
\text { not exert a direct effect on steady- state growth. }\end{array}$ \\
\hline $\begin{array}{l}\text { McCaig and } \\
\text { Stengos } \\
(2005)\end{array}$ & $\begin{array}{l}\text { Annual Data of } 71 \\
\text { countries over the } \\
\text { period (1960-1995) }\end{array}$ & $\begin{array}{l}\text { GMM and } \\
\text { OIR }\end{array}$ & $\begin{array}{l}\text { A strong positive effect of financial development on economic growth when } \\
\text { private domestic credit or liquid liabilities is used as the measures of financial } \\
\text { development. }\end{array}$ \\
\hline $\begin{array}{l}\text { Apergis et } \\
\text { al. (2007) }\end{array}$ & $\begin{array}{l}\text { Annual Data of } 101 \\
\text { countries over the } \\
\text { period }(1975-2000)\end{array}$ & $\begin{array}{l}\text { Panel Data } \\
\text { Cointegration } \\
\text { Methodology }\end{array}$ & $\begin{array}{l}\text { The financial development and economic growth have strong relationship and the } \\
\text { causality is bidirectional. }\end{array}$ \\
\hline $\begin{array}{l}\text { Caporale et } \\
\text { al. }(2009)\end{array}$ & $\begin{array}{l}\text { Annual Data of } 10 \\
\text { EU countries over } \\
\text { the period (1994- } \\
\text { 2007) }\end{array}$ & GMM & $\begin{array}{l}\text { Causality of the finance-growth relationship is unidirectional, and runs from } \\
\text { financial development to growth. }\end{array}$ \\
\hline $\begin{array}{l}\text { Bangake } \\
\text { and Eggoh } \\
(2011)\end{array}$ & $\begin{array}{l}\text { Annual data of } 71 \\
\text { developed and } \\
\text { developing } \\
\text { countries }\end{array}$ & VECM & $\begin{array}{l}\text { Toward bi-directional causality in the long run across country groups. In the short } \\
\text { run, however, the direction of causality goes from growth to finance for the high } \\
\text { income countries, while folow and middle income countries they cannot find any } \\
\text { evidence of causality }\end{array}$ \\
\hline
\end{tabular}

Source: Author's Construction

\section{Time Series Studies}

A time series literature analyzed the finance-growth relationship by using the various time series techniques. The time series studies use VAR procedures and Granger causality tests to scrutinize the relationship between financial development and economic growth. The research improved the measures of financial development and performed in-depth analysis on an individual country.

Gupta (1984) estimates the data of 14 countries over the period of 1961-1980. The Author's model estimates for financial savings in physical assets for the countries to test the sub-hypothesis contained in the complementary hypothesis that financial savings are highly sensitive to movement of real interest rates and their stability. Further the author examines real interest rates and their stability pertaining to the matters in the economies of developing countries by using VAR and Granger causality test. This study concludes that financial development has a positive impact on economic growth.

Jung (1986) evaluates the data of 56 countries in which 37 are developing, and 19 are developed countries by using VAR and Granger causality methods. The study uses different variables of financial development ${ }^{30}$ and economic growth ${ }^{31}$ to determine the causality between financial development and economic growth. The study emphasizes that the financial development has a strong positive impact on developing countries, but a reverse relationship has been found in the developed countries.

Demetriades and Hussein (1996) analyze the data of 16 countries $^{32}$ with at least 27 observations by using a different proxy of financial development ${ }^{33}$. They find little support to the view that finance is a leading sector in the process of economic development. However, they find that the relationship between financial development and economic growth is bi-directional. They conclude that where reforms are able to contribute to the process of financial deepening, it may contribute to the more general process of economic development.

\footnotetext{
${ }^{30}$ These variables are: (i) Currency to M1 (ii) M2 to GDP ratio.

${ }^{31}$ The variable is per capita GDP.

${ }^{32}$ These countries were Costa Rica, Greece, El Salvador, Guatemala, Honduras, India, Korea, Mauritius, Pakistan, Portugal, South Africa, Spain, Sri Lanka, Thailand, Turkey and Venezuela

${ }^{33} \mathrm{M} 2$ minus currency to GDP
} 
Arestis and Demetriades (1997) estimate the quarterly data of Germany and US for the period 1979-1991 by using Johansen Cointegration, VECM and Weak Exogeneity Tests. Their study concludes that the cross-country analysis for the evaluation of the link between the financial development and economic growth is limited. In Germany, financial development has a positive impact on economic growth were as in the US; the connection between financial development and economic growth has been disapproved.

Rousseau and Wachtel (1998) analyze the data for five countries ${ }^{34}$ over the period 18701929 and conduct time-series tests of financial development and economic growth by using a measure of financial development that includes the assets of both banks and nonbanks. They also evaluate the causality between real per capita level of output, money and the assets of the institutions by using Vector Error Correction Models (VECMs) and Granger Causality techniques. The results suggest that financial intermediation leads to economic growth. Thus, the dominant direction of causality runs from financial development to economic growth.

Rousseau (1999) analyzes to know whether financial development leads to higher investment rates and per capita income of Japan over the period 1880 to 1913 by using different economic growth and financial development factors ${ }^{35}$. The study shows that the correlation between financial developments and real growth by illustrating with standard macroeconometric techniques such as Vector Autoregressive (VAR) for the historical time series that are available for Meiji Japan (1880-1913) are consistent with the "financeled" growth hypothesis.

Rousseau and Sylla (1999) analyzed the data of US economy over the period of 17921850 by using Vector Autoregressive (VAR) models to determine the relationship between financial development and real economic growth. Their study develops several annual time series evaluations of financial development and real economic growth. The study concludes that the finance - growth relationship is not bidirectional, financial development has a positive impact on economic growth but there is no feedback of real economic growth on financial development.

Jackson and Fethi (2000) examine the performance of the Turkish banking sector by applying $\mathrm{DEA}^{36}$ and then discovered the determinants of efficiency from a set of explanatory variables (bank size, number of branches, profitability, and ownership and capital adequacy ratio) by the using of Tobit model. They define performance of a bank in terms of its ability to produce outputs with a minimum use of inputs. For this study, they use the data of year 1998 and considered number of employees and the sum of non labor expenses as inputs of the bank. They find significant negative impact of capital adequacy ratio and significant positive impact of profitability, size and efficiency of the bank.

Arestis et al. (2001) utilize time series methods and analyze the data of five countries ${ }^{37}$ by using proxies of output ( Real GDP), stock market development (Ratio of stock market capitalization to GDP), banking sector development (Ratio of domestic credit to GDP)

\footnotetext{
${ }^{34}$ These countries were Canada, Norway and Sweden, U.S and U.K.,

${ }^{35}$ These factors are: (i) GNP, (ii) Ratio of Gross Fixed Investment with GNP, (iii) total financial intermediary assets, (iv) intermediary assets, corporate stocks and bonds and (v) currency in circulation.

${ }^{36}$ Data Envelopment Analysis (DEA) is linear programming based technique for measuring the relative performance of organizational units where the presence of multiple inputs and outputs makes comparisons difficult.

${ }^{37}$ These countries were Germany, United States, Japan, United Kingdom, and France
} 
and stock market volatility ( Eight-quarter moving standard deviation of the end-ofquarter change of stock market prices) to determine the relationship between stock market development and economic growth, controlling the effects of the banking system and stock market volatility. They conclude that, both stock market and banking development enhance a higher economic growth but contribution of stock market development on economic growth has embroidered by studies that utilize cross-country growth regression. Thus, their results could be indirectly useful for developing countries as it can inform policy decision makers on the adoption or otherwise of specific types of the financial system.

Fase and Abma (2003) determine the impact of financial development on economic growth with annual data of the nine countries ${ }^{38}$ of Asia over the period 1978-1999 by using Error Correction Model and hypothesis was tested with the Augmented Dickey Fuller (ADF) test. They used different measures ${ }^{39}$ of financial development and economic growth and found that causality runs from the stage of financial intermediation and superiority to growth. The results attained for the nine single countries are strengthened by the examination of collective data across the countries, suggesting a more or less identical pattern of performance of economic growth. The findings indicate that a policy of financial reform in the selected countries is likely to progress towards the economic growth.

Honda (2003) inspects the impact of financial deregulation in Japan's heavily regulated financial system between 1980s and 1996. The results of the study reveal that although the Financial, Big Bang reforms put into practice in 1996 endeavored to reform the Japanese financial sector in a very comprehensive and quick manner to be totally compatible with the global standards in advanced economies, successful deregulation of the financial sector, requires careful contemplations on time-sequencing, speed, and strengthening of bank supervision capacity.

Iimi (2004) examines the impact of banking sector reforms in Pakistan based on economies of scale and scope, and cost complementarities. The author analyzes the plan that even though banking sector development was important for the early stage of economic growth, general liberalization presuming an identical bank role might not necessarily promote growth. The estimated cost structure indicated that state-owned commercial banks were large enough, while development financial institutions and private banks could be expecting to obtain cost-saving advantages by increasing their operations. Since the extent, economies have been significant, portfolio diversification generally increased bank profits. In addition, privatized banks were the most efficient, followed by foreign and private banks. Public banks are the least efficient.

Khan, et al. (2005) tested the relationship between financial development and economic growth for Pakistan over the period 1971-2004, using Autoregressive Distributed Lag (ARDL) technique. The results of the study showed that in the long-run financial depth, and real interest rate exerts a positive impact on economic growth. However, the relationship between growth and financial development is through positive but remained insignificant in the short-run. They concluded that growth is an outcome of financial development.

\footnotetext{
${ }^{38}$ These countries were Bangladesh, India, Malaysia, Pakistan, Philippines, Singapore, South Korea, Sri Lanka, and Thailand

${ }^{39}$ These measures were GDP growth, capital investment and Financial assets
} 
Moore et al. (2006) apply stochastic simulation methods to a system-wide flow of funds model for India for 1951-1994 to examine two issues. The foremost concerned the impact of financial reforms on interest rates and loanable funds. The next was to assess the robustness of policy if there was some uncertainty about the accurate model. The results of their study show significant discrepancies in policy risk depending on the policy mechanism and the policy regime. Interest rate risks were found to be superior in the controlled policy regime; while quantity risks were superior in the liberalized policy regime. The results of their study also revealed that outcomes depended much on controls on intermediaries: more heavily controlled banks responded differently from other less heavily controlled financial intermediaries.

Das and Ghosh (2006) investigate the performance of the Indian commercial banking sector during the post reform period 1992-2002. They evaluate some efficiency estimates of individual banks using nonparametric Data Envelopment Analysis (DEA). Their analysis link variations in calculated efficiencies to a set of variables, i.e., bank size, ownership, capital adequacy ratio, non-performing loans and management quality. Contrary to the negative perceived view on liberalization, the results of their study proved that medium-sized public sector banks performed reasonably well and were more likely to operate at higher levels of technical efficiency. A close relationship was observed between efficiency and soundness as determined by a bank's capital adequacy ratio. The empirical results also showed that technically more efficient banks were those that had, on average, less non-performing loans as a ratio of total assets.

Burki and Niazi (2006) investigate the impact of financial reforms on banking efficiency of state-owned, private, and foreign banks in Pakistan. They find that foreign banks have better efficiency scores during 1993-1996 and confirm a negative relationship between the size of a bank and its efficiency score. Ataullah et al. (2004) find evidence that financial deregulation has a positive impact on bank efficiency in both India and Pakistan. Using data for the period 1988-1998, they show that overall technical efficiency of the banking sector increases following financial liberalization, especially after 1995-1996. Hardy and Patti (2001) investigate the effects of financial reforms on profitability, cost and revenue efficiency of the banking sector in Pakistan's banks during 1981- 1998. They show that financial liberalization has a positive impact on banking sector performance. In particular, cost and revenue efficiency of banks increases, following financial liberalization policies. Abu-Bader and Abu Qarn (2008) equally provide evidence in support of finance-led growth. They scrutinize the fundamental relationship between financial development and economic growth of six countries ${ }^{40}$ over the period 1960-2004, by utilizing four different measures of financial development and applied Vector Autoregressive (VAR), Granger causality tests, cointegration test and Vector Error Correction Models (VECMs). Their results support that finance leads growth in most of the countries. Their results show the need to accelerate financial reforms for the improvement of the efficiency of financial systems in these countries to encourage savings and investment and thus enhance the long-run economic growth.

Jenkins and Katircioglu (2009) test the supply-leading, export-led growth and import-led growth hypotheses in the case of Cyprus but do not confirm them whereas the demandfollowing hypothesis was justified for the Cypriot economy when M2 measure of money supply is under consideration.

\footnotetext{
${ }^{40}$ These countries were Algeria, Egypt, Israel, Morocco, Syria and Tunisia
} 
Katircioglu et al. (2007) carry out similar research for India and find that financial sector is a determinant of real income in India. Furthermore, selected financial development proxies and real income growth are in feedback relationship in the case of India.

Table 2 summarizes the key findings of time-series studies on financial development and economic growth.

Table 2: Time Series Evidence on Finance and Growth

\begin{tabular}{|c|c|c|c|}
\hline Study & Sample & Method & Key findings \\
\hline $\begin{array}{l}\text { Gupta } \\
(\mathbf{1 9 8 4})\end{array}$ & $\begin{array}{l}\text { Annually data of } 14 \\
\text { countries over the } \\
\text { period of } 1961-1980\end{array}$ & $\begin{array}{l}\text { VAR and } \\
\text { Granger } \\
\text { causality }\end{array}$ & $\begin{array}{l}\text { Causality runs from financial development to economic growth } \\
\text { and this phenomenon is bidirectional. }\end{array}$ \\
\hline $\begin{array}{l}\text { Jung } \\
(\mathbf{1 9 8 6})\end{array}$ & $\begin{array}{l}\text { Annually data of } 56 \\
\text { countries in } 37 \text { are } \\
\text { developing and } 19 \\
\text { are developed } \\
\text { countries }\end{array}$ & $\begin{array}{l}\text { VAR and } \\
\text { Granger } \\
\text { causality }\end{array}$ & $\begin{array}{l}\text { Financial development has a strong positive impact on developing } \\
\text { countries but a reverse relationship has been found in the } \\
\text { developed countries. }\end{array}$ \\
\hline Study & Sample & Method & Key findings \\
\hline $\begin{array}{l}\text { Demetria- } \\
\text { des and } \\
\text { Hussein } \\
\text { (1996) }\end{array}$ & $\begin{array}{l}\text { Annually data from } \\
16 \text { countries }\end{array}$ & $\begin{array}{l}\text { Granger } \\
\text { Causality }\end{array}$ & $\begin{array}{l}\text { There is bidirectional relationship between economic growth and } \\
\text { financial reforms. This relationship has a positive impact on the } \\
\text { process of economic growth. }\end{array}$ \\
\hline $\begin{array}{l}\text { Arestis } \\
\text { and } \\
\text { Demetria } \\
\text { des } \\
(1997) \\
\end{array}$ & $\begin{array}{l}\text { Quarterly data over } \\
\text { the period 1979-1991 }\end{array}$ & $\begin{array}{l}\text { Johansen } \\
\text { Cointegration, } \\
\text { VECM and } \\
\text { weak } \\
\text { Exogeneity } \\
\end{array}$ & $\begin{array}{l}\text { In Germany, financial development has a positive impact on } \\
\text { economic growth where as in the US; the connection between } \\
\text { them has been disapproved. }\end{array}$ \\
\hline $\begin{array}{l}\text { Rousseau } \\
\text { and } \\
\text { Wachtel } \\
(\mathbf{1 9 9 8 )}\end{array}$ & $\begin{array}{l}\text { Annual data over the } \\
\text { period } 1870-1929\end{array}$ & $\begin{array}{l}\text { VECMs and } \\
\text { Granger } \\
\text { Causality }\end{array}$ & $\begin{array}{l}\text { Financial intermediation leads to economic growth but it doesn't } \\
\text { have the same effect on financial development. }\end{array}$ \\
\hline $\begin{array}{l}\text { Rousseau } \\
\text { (1999) }\end{array}$ & $\begin{array}{l}\text { Annual data for } 5 \\
\text { Countries over the } \\
\text { period } 1880-1913 \\
\end{array}$ & VAR & $\begin{array}{l}\text { The financial development has strong impact on economic growth } \\
\text { of Japan. }\end{array}$ \\
\hline $\begin{array}{l}\text { Rousseau } \\
\text { and Sylla } \\
(1999)\end{array}$ & $\begin{array}{l}\text { Annual data over the } \\
\text { period of } 1792-1850\end{array}$ & VAR & $\begin{array}{l}\text { The finance - growth relationship is not bidirectional, financial } \\
\text { development has a positive impact on economic growth but there } \\
\text { is no feedback of real growth in finance. }\end{array}$ \\
\hline $\begin{array}{l}\text { Jackson } \\
\text { and Fethi } \\
(2000)\end{array}$ & $\begin{array}{l}\text { Examine Turkish } \\
\text { banking sector }\end{array}$ & DEA & $\begin{array}{l}\text { Significant negative impact of capital adequacy ratio and } \\
\text { significant positive impact of profitability and size of the bank on } \\
\text { estimated efficiency. }\end{array}$ \\
\hline $\begin{array}{l}\text { Arestis, } \\
\text { Demetria } \\
\text { des and } \\
\text { Luintel } \\
(2001) \\
\end{array}$ & $\begin{array}{l}\text { Annual data of } 5 \\
\text { Countries }\end{array}$ & OLS & $\begin{array}{l}\text { Their results could be indirectly useful for LDCs economies, as } \\
\text { it can inform policy decision-makers on the adoption or } \\
\text { otherwise of specific types of financial system. }\end{array}$ \\
\hline $\begin{array}{l}\text { Fase and } \\
\text { Abma } \\
(\mathbf{2 0 0 3 )}\end{array}$ & $\begin{array}{l}\text { Annual data of over } \\
\text { the period } 1978-1999\end{array}$ & $\begin{array}{l}\text { Error } \\
\text { Correction } \\
\text { Model and } \\
\text { ADF }\end{array}$ & $\begin{array}{l}\text { A policy of financial reform in the selected countries is likely to } \\
\text { boom the economic growth. }\end{array}$ \\
\hline $\begin{array}{l}\text { Khan, et } \\
\text { al. (2005) }\end{array}$ & $\begin{array}{l}\text { Annual data of } \\
\text { Pakistan the period } \\
(1971-2004)\end{array}$ & ARDL & $\begin{array}{l}\text { Financial development and real interest rate have a positive and } \\
\text { significant impact on economic growth in the long-run but in } \\
\text { short run the impact is positive but not significant. }\end{array}$ \\
\hline $\begin{array}{l}\text { Abu- } \\
\text { Bader and } \\
\text { Abu Qarn } \\
\text { (2008) }\end{array}$ & $\begin{array}{l}\text { Annual data over the } \\
\text { periods (1960-2004) }\end{array}$ & $\begin{array}{l}\text { VAR, } \\
\text { Granger } \\
\text { causality, } \\
\text { cointegration } \\
\text { and VEC } \\
\end{array}$ & $\begin{array}{l}\text { The need to accelerate financial reforms improved the efficiency } \\
\text { of financial systems to encourage savings and investment and } \\
\text { thus the long-term economic growth. }\end{array}$ \\
\hline $\begin{array}{l}\text { Jenkins } \\
\text { and } \\
\text { Katircio- } \\
\text { glu (2009) }\end{array}$ & $\begin{array}{l}\text { Annual Data of } \\
\text { Cyprus over the } \\
1960-2005 \text { Period }\end{array}$ & $\begin{array}{l}\text { VEC Model } \\
\text { and Causality } \\
\text { Analysis }\end{array}$ & $\begin{array}{l}\text { The supply-leading, export-led growth, and import-led growth } \\
\text { hypotheses are not confirmed by this study whereas the demand- } \\
\text { following hypothesis can be justified for the Cypriot economy } \\
\text { when M2 measure of money supply is under consideration. }\end{array}$ \\
\hline
\end{tabular}




\begin{tabular}{|l|l|l|l|}
\hline $\begin{array}{l}\text { Katircio- } \\
\text { glu et al. } \\
\mathbf{( 2 0 0 7 )}\end{array}$ & $\begin{array}{l}\text { Annual Data of India } \\
\text { over the 1960-2004 } \\
\text { Period }\end{array}$ & $\begin{array}{l}\text { VEC Model } \\
\text { and Causality } \\
\text { Analysis }\end{array}$ & $\begin{array}{l}\text { Financial sector is a determinant of income in India. Financial } \\
\text { development and real income growth are in feedback relationship. }\end{array}$ \\
\hline
\end{tabular}

Source: Author's Construction.

Overall, recent empirical evidence from cross-country and time-series studies suggests that financial development is an important determinant of economic growth. However, the impact may be nonlinear. This could be especially true in countries with very low institutional quality, where financial deepening may not translate into higher economic growth.

\section{Conclusion}

This study reviews the theoretical literature as well as empirical literature of the financegrowth nexus within a growth structure. It is obvious that financial development is directly co-related to economic growth. In spite of the inadequacies of the cross-country growth regression structure there emerges to be a comparatively strong correlation between financial development and economic growth. Even though this correlation comes into sight quite vigorously, it is hard to move forward on causality with such a crosscountry approach. Cross-country studies reveal that financial development exerts a disproportionately positive impact on economic growth. On the other hand, time series studies also prove that finance is a leading factor in the process of growth. This study reveals that searching the relationship between financial development and economic growth is inconclusive across countries, regions, and methodologies employed.

\section{References}

[1] Abu-Bader, S. and Abu-Qarn, A. M, 2008. "Financial Development and Economic Growth: Empirical Evidence from MENA Countries", Review of Development Economics, 12, pp.803-817.

[2] Acemoglu, D. and Zilibotti, F, 1997. "Was Prometheus Unbound by Chance? Risk, Diversification, and Growth. Journal of Political Economy (105:4), pp. 709-751.

[3] Aghion, P. et al, 2005. "Volatility and Growth: Credit Constraints and ProductivityEnhancing Investment", National Bureau of Economic Research (NBER) Working Paper 11349.

[4] Apergis N., Filippidis I., and Economidou C, 2007, "Financial Deepening and Economic Growth Linkages: a Panel Data Analysis", Review of World Economics 43, pp.179-198.

[5] Arestis, P. and Demetriades, P, 1997, "Financial Development and Economic Growth: Assessing the Evidence", Economic Journal 107, pp.783-99.

[6] Arestis, P., Demetriades, P., and Luintel, K, 2001. "Financial Development and Economic Growth: The Role of Stock Markets", Journal of Money, Credit, and Banking 33, pp.16-41.

[7] Ataullah, A., Cockerill, T. and Le, H, 2004. "Financial Liberalization and Bank Efficiency: A Comparative Analysis of India and Pakistan", Applied Economics, (36:17), pp.1915-1924. 
[8] Atje, R. and Jovanovic, B, 1993. "Stock Markets and Development", European Economic Review 37, pp.632-640.

[9] Bagehot, W, 1873. "Lombard Street: A Description of the Money Market. Homewood", IL: Richard D. Irwin (1962 Edition).

[10] Bangake, C. and Eggoh, J. (2011), Further evidence on finance-growth causality: A panel data analysis, Economic Systems, 35:176-188.

[11] Bencivenga, V. R. and Smith, B. D, 1991. "Financial Intermediation and Endogenous Growth", Review of Economic Studies (58:2), pp.195-209.

[12] Bencivenga, V. R. and Smith, B. D, 1993. "Some Consequences of Credit Rationing in an Endogenous Growth Model", Journal of Economic Dynamics and Control 17, pp.97-122.

[13] Bencivenga, V. R., Smith B. D. and Starr, R. M, 1995. "Transactions Costs, Technological Choice, and Endogenous Growth", Journal of Economic Theory 67 pp. 53-177.

[14] Blackburn, K. and Hung, V.T.Y, 1998. "A Theory of Growth, Financial Development, and Trade", Economica 65, pp. 107-24.

[15] Boyd, J. H. and Prescott E. C, 1986. "Financial Intermediary-Coalitions", Journal of Economics Theory 38, pp. 211-232.

[16] Burki, A.A. and Niazi, G.S.K, 2006. "Impact of Financial Reforms on Efficiency of State-owned, Private and Foreign Banks in Pakistan", Centre for Management of Economic Research (CMER) Working Paper 49, Lahore University of Management Sciences, Lahore, Pakistan.

[17] Christopoulos, D.K., and Tsionas, E.G, 2004. "Financial Development and Economic Growth: Evidence from Panel Unit Root and Cointegration Tests", Journal of Development Economics (73:1), pp. 55-74.

[18] Caporale, G., M., Rault, C., Sova, R. (2009), Financial Development and Economic Growth: Evidence from Ten New EU Members, Deutsches Institut für Wirtschaftsforschung, Discussion Paper 940.

[19] Darrat, A.F, 1999. "Are Financial Deepening and Economic Growth Causally Related? Another Look at the Evidence", International Economics Journal 13, pp. 19-35.

[20] Das, A and Ghosh, S, 2006. "Financial Deregulation and Efficiency: An Empirical Analysis of Indian Banks during the Post Reform Period", Review of Financial Economics, (15:3), pp.193-221.

[21] De Gregorio, J, 1996. "Borrowing Constraints, Human Capital Accumulation, and Growth", Journal of Monetary Economics 37 pp. 49-71.

[22] De la Fuente, A. and J. M. Marin, 1996. "Innovation, Bank Monitoring and Endogenous Financial Development", Journal of Monetary Economics 38, pp. 269301.

[23] Demetriades, P. and K. A. Hussein, 1996. "Does Financial Development Cause Economic Growth? Time Series Evidence from 16 Countries", Journal of Development Economics 51, pp. 387-411.

[24] Demirgüç-Kunt, A. and V. Maksimovic, 2002. "Funding Growth in Bank-Based and Market-Based Financial Systems: Evidence from Firm Level Data", Journal of Financial Economic 65, pp.337-363.

[25] Demirguc-Kunt, Asli and Vojislav Maksimovic, 1998. "Law, finance and firm growth", Journal of Finance (53:6), pp. 2107-2137. 
[26] Diamond, D. W, 1984. "Financial Intermediation and Delegated Monitoring", Review of Economic Studies 51, pp.393-414.

[27] Fase, M.M.G. and Abma, R.C.N, 2003. "Financial Environment and Economic Growth in Selected Asian Countries", Journal of Asian Economics, (14:1), pp. 1121.

[28] Galetovic, A., 1996. "Specialization, intermediation and growth", Journal of Monetary Economics 38, pp.549-559.

[29] Goldsmith, R, 1969. "Financial Structure and Development", New Haven: Yale University Press.

[30] Greenwood, J. and B. Jovanovic, 1990. "Financial Development, Growth and the Distribution of Income", Journal of Political Economy, (98:5), pp. 1076-1107.

[31] Greenwood, J. and Smith, B, 1997. "Financial Markets in Development, and the Development of Financial Markets", Journal of Economic Dynamics and Control 21, pp. 145-181.

[32] Gupta, K.L, 1984, "Finance and Economic Growth in Developing Countries", $1^{\text {st }}$ Ed., Croom Helm 241.

[33] Gurley, J. and Shaw. E, 1967. "Financial Structure and Economic Development", Economic Development and Cultural Change (34:2), pp.33-46.

[34] Hardy, Daniel C., and Emilia Bonaccorsi De Patti, 2001. "Bank Reforms and Bank Efficiency in Pakistan", IMF Working Paper 138.

[35] Harris, Richard D. F, 1997. "Stock Markets and Development: A Re-Assessment", European Economic Review 41, pp. 39-146.

[36] Harrison, P., O. Sussman and J. Zeira, 1999. "Finance and Growth: Theory and Evidence", Washington, DC: Federal Reserve Board.

[37] Hicks, J, 1969. "A Theory of Economic History", Oxford: Clarendon Press.

[38] Holmstrom, B. and Tirole, J, 1998. "Private and Public Supply of Liquidity", Journal of Political Economy 106, pp. 1-40.

[39] Honda, E, 2003. "Financial Deregulation in Japan", Japan and the World Economy (15:1), pp. 135-140.

[40] Iimi, A, 2004. "Banking Sector Reforms in Pakistan: Economies of Scale and Scope, and Cost Complementarities", Journal of Asian Economics (15:3), pp. 507-528.

[41] Jackson, P.M. and Fethi, M.D, 2000. "Evaluating the efficiency of Turkish commercial banks: An application of DEA and Tobit Analysis", presented at the International DEA Symposium, University of Queensland, Brisbane, Australia, pp. $2-4$.

[42] Jacoby, H. G, 1994. "Borrowing Constraints and Progress through School: Evidence from Peru", Review of Economics and Statistics (76:1), pp. 151-60.

[43] Jenkins, H. P. and Katircioglu, S. (2010), The Bounds Test Approach for Cointegration and Causality between Financial Development, International Trade and Economic Growth: The Case of Cyprus, Applied Economics, 42 (13): 16991707.

[44] Jung, W. S, 1986. "Financial Development and Economic Growth: International Evidence", Economic Development and Cultural Change 34, pp. 333-346.

[45] Katircioglu, S., Kahyalar, N. and Benar, H. (2007), Financial Development, Trade and Growth Triangle: The Case of India, International Journal of Social Economics, 34 (9): 586-598. 
[46] Khan, M. A, A. Qayyum, and S. A. Sheikh, 2005. "Financial Development and Economic Growth: The Case of Pakistan", Pakistan Development Review (44:4), pp. 819-837.

[47] King, R. G. and Levine, R, 1993b. "Finance and Growth: Schumpeter Might be Right", Quarterly Journal of Economics (108:3), pp. 717-737.

[48] Laeven, L. and Levine, R, 2008. "Complex Ownership Structures and Corporate Valuations", Review of Financial Studies 21, pp.579-604.

[49] Levine, R, 1999, "Law, Finance, and Economic Growth", Journal of Financial Intermediation 8, pp. 36-67.

[50] Levine, R, 2004. "Finance and Growth: Theory and Evidence", National Bureau of Economic Research (NBER), WP 10766.

[51] Levine, R. and S. Zervos, 1998. "Stock Markets, Banks, and Economic Growth", American Economic Review (88:3), pp. 537-558.

[52] Levine, R., N. Loayza and T. Beck, 2000, "Financial Intermediation and Growth: Causality and Causes", Journal of Monetary Economics 46, pp.31-77.

[53] Levine, Ross, 2006. "Finance and Growth: Theory and Evidence in Handbook of Economic Growth", Eds: Philippe Aghion and Steven Durlauf, New York: Elsevier North-Holland, pp. 865-934.

[54] McCaig, B. and T. Stengos, 2005. "Financial Intermediation and Growth: Some Robustness Results". Economics Letters 88, pp. 306-312.

[55] McKinnon, R. I, 1973. "Money and Capital in Economic Development", Washington, DC, The Brookings Institution.

[56] Moore, T, Green, J. C, and Murinde, V, 2006. "Financial Sector Reforms and Stochastic Policy Simulations: A flow of funds model for India", Journal of Policy Modeling (28:3), pp. 319-333.

[57] Patrick, H. T, 1966. "Financial Development and Economic Growth in Underdeveloped Countries", Economic Development and Cultural Change 14, pp. 174-189.

[58] Phillips, P. C. B. and Perron, P. P, 1988. "Testing for a Unit Root in Time Series Regression”, Biometrika (75:2), pp.335-346.

[59] Rioja, F., and Valev, N, 2003. "Finance and the Sources of Growth at Various Stages of Economic Development", Economic Inquiry (42:1), 127-140.

[60] Roubini, N. and Sala-i-Martin. X, 1992. "Financial Repression and Economic Growth", Journal of Development Economics 39, pp. 5-30.

[61] Rousseau, P. and Sylla R, 1999. "Emerging Financial Markets and Early U.S. Growth", National Bureau of Economic Research (NBER), WP 7448.

[62] Rousseau, P. L. and Wachtel, P, 1998. "Financial Intermediation and Economic Performance: Historical Evidence from Five Industrialized Countries", Journal of Money, Credit and Banking 30, PP. 657-678.

[63] Rousseau, Peter L, 1999. "Finance, investment, and growth in Meiji-era Japan", Japan and the World Economy, Elsevier (11:2), 185-198.

[64] Schumpeter, J. A, 1912. "The Theory of Economic Development", Cambridge, MA: Harvard University Press, 1934.

[65] Shaw, E. S, 1973. "Financial Deepening in Economic Development", New York: Oxford University Press.

[66] Shleifer, A. and Vishny, R. W, 1996. "A Survey of Corporate Governance", National Bureau of Economic Research (NBER), WP 5554. 
[67] Sirri, E. R. and P. Tufano, 1995. "The Economics of Pooling, In: The Global Financial System: A Functional Approach", Eds: D. B. Crane, et al., Boston, MA: Harvard Business School Press: 81-128.

[68] Smith, Adam, 1776. "An Inquiry into the Nature and Causes of the Wealth of Nations", Oxford: The Clarendon Press.

[69] Sussman, O, 1993. "A Theory of Financial Development, In: Finance and Development: Issues and Experience", Ed: A. Giovannini, Cambridge University Press.

[70] $\mathrm{Xu}, \mathrm{Z}, 2000$. "Financial Development, Investment, and Economic Growth", Economic Inquiry, 38, pp. 331-344. 